\title{
Hepatoprotective Effects Of Gambia Albidum Bark Extract
}

\author{
Aloh Godwin Sunday ${ }^{1}$, Obeagu Emmanuel Ifeanyi ${ }^{2}$, Onyeonoru Tochi C. ${ }^{3}$ \\ 1.Lecturer,Department of Biochemistry,Michael Okpara University of Agriculture,Umudike,Abia State,Nigeria. \\ 2.Diagnostic Laboratory Unit,University Health Services Department, Michael Okpara University of \\ Agriculture,Umudike,Abia State,Nigeria. \\ 3.Department of Biochemistry,Ebonyi State University,Abakaliki,Nigeria.
}

\begin{abstract}
The hepatoprotective effects of ethanol and ethyl acetate extracts of Gambia albidum were investigated on albino rats. The rats were grouped into four, $A, B, C$ and $D$, in which $A$ and $B$ were positive and negative controls respectively. Hepatotoxicity was induced in group A with carbon tetrachloride only but not treated while it was not induced in (group B), the positive control. The hepatotoxicity induced in group $C$ animals was treated with steam-borne ethanol extract while that of group D with ethyl acetate extract. The parameters measured were lipid peroxidation products, bilirubin, AST, protein, cholesterol. The mean lipid peroxidation values are $0.026 \pm 0.0027,0.031 \pm 0.040,0.029 \pm 0.005$ and $0.032 \pm 0.002$ for groups $A, B, C$ and $D$ respectively. The corresponding mean values for cholesterol were $3.91 \pm 0.050,0.42 \pm 0.006,0.39 \pm 0.009$, and $0.407 \pm 0.015,3.790 \pm 0.235$ for group $A, B, C$ and $D$ respectively. The corresponding values for bilirubin were $23.58 \pm 0.764,16.50 \pm 2.046,21.92 \pm 3.753$ and $13.00 \pm 0.750$ for group $A, B, C$, and $D$ respectively. The corresponding values of AST were $145 \pm 1.071,135.89 \pm 1.614,142.89 \pm 11.042$ and $119.33 \pm 2.728$ for group $A, B, C$ and $D$ respectively. Based on the above results, the two extracts, (ethanol and ethyl acetate) of Gambia albidum were moderately effective in providing protection against $\mathrm{CCI}_{4}$-induced hepatotoxicity.
\end{abstract}

Keywords:Gambia albidium, hepatoprotective effects, Lipid Peroxidation, bilirubin, cholesterol, AST and Protein.

\section{Introduction}

Medicinal plants are a very popular subject of research in the chemical and biological sciences of most developing countries. In all countries of the world, traditional medicine relates to the health of human and animals. This traditional medicine is a major African socio-cultural heritage, obviously in existence for several hundreds of years.

Traditional medicine is an act using plant leaves, barks, roots or any other parts of plants in the crude form for treatment of various diseases. Plant bark and leaves are most used in tradomedicine. In some cases, plant barks are eaten raw, soaked or parboiled to extract the active ingredients contained in the plant.

Many years ago, traditional medicine was the only means of curing infections. There was enough technological development and less orthodox drugs in circulation especially in underdeveloped part of Africa and Asia world.

However, today traditional medicine has been brought into focus for meeting the goals of a wider coverage of primary health care delivery, not only in Africa but in all countries of the world.

Traditional medicine, according to World Health Organization (WHO, 1978) is the sum total of knowledge or practice either explicable or inexplicable used in diagnosing preventing or eliminating a physical mental or social disease, which rely exclusive on past experience or observation, handed down from generation to generation verbally or in writing. It also comprises therapeutic practices that have been in existence often for hundred years before the development of modern scientific medicine and are still in use today, without any documented evidence or adverse effect, if properly used.

However, following the advancement in technology, synthetic drugs seem to displace traditional medicine and the crave for it is so high that it competes favorably with synthetic medicines. Hence, there is considerable attention shifting from synthetic drugs to the use of medicinal plants.

Medicinal plans exist all over the world as grasses, shrubs, trees e.t.c. medicinal plans are whose organs or parts could be used for therapeutic purposes. A typical example of medicinal plant is Gambia Albidium. It is a Genus of about 70-80 species of tropical trees growing rapidly to $10-20 \mathrm{~m}$ or more in height. The genus is native to tropical regions throughout the world, with the greatest number of species in northern South America. The leaves are oval, $3-15 \mathrm{~cm}$ long, green above, densely golden pubescent below from which the genus is named. The flowers are small $(3-8 \mathrm{~mm})$ purplish white and have a sweet fragrant smell. They are clustered several together and are hermaphroditic (self fertile). The fruit is edible, round, usually purple skinned (sometimes greenish white), often green around the calyx, With a star pattern in the pulp. The flattened seeds are light brown and hard. The fruit skin is chewy and contrary to some reports it's edible. 
Generally, their leaves, barks and roots could be processed in various types of disease. Such as cancer, stomach upset, dysentery, diarrhea and hemorrhage.

Hepatoprotection or anti hepatotoxicity is the ability to prevent damage to the liver. Hepato protective agents are agents administered before with of after cancer therapy to reduce or prevent damage or toxicity to the liver. Hepatoprotective agent is from group of chemoprotective. Example of hepatoprotective medicine is slibinin, derived from thistle, which selectively inhibits leukotriene formation by kupffer cells.

The mechanism of hepatoprotective are diverse and include antioxidant activity, direct antiviral effects, enhancement for interferon production, enhanced antibody production, enhancement of extrathymic Tcell activity in the liver and protection from immunological (autoimmune) injuries. A number of animal and vitro trials have shown that glycyrrhizin can protect liver cells from damage from a variety of chemicals or immunological agents.

\section{AIMS AND OBJECTIVE}

To ascertain the hepatoprotectivity effect of Gambia Albidium bark on rats.

\section{MATERIALS}

\section{Materials And Methods}

\section{BIOLOGICAL MATERIALS}

Albino rats

Bark of Gambia Albidium

\section{METHODS}

\section{COLLECTION OF SAMPLES}

COLLECTIOM OF GAMBIA ALBIDIUM BARK EXTRACT

$400 \mathrm{~g}$ of Gambia albidium bark was collected from the tree at Nsukka in Enugu State. The bark was crushed at the laboratory unit of Biochemistry department of University of Nigeria, Nsukka using a manual blender.

\section{EXTRACTION OF PLANTS MATERIALS}

The powdered form of Gambia Albidium bark was extracted using Ethylacetate and Ethanol respectively by soaking the ground bark and left overnight $(24 \mathrm{hrs})$ and it is filtered with cheese cloth. The extract was concentrated using an oven, the ethylacetate extract was concentrated at $70^{\circ} \mathrm{C}$ while he ethanol extract was concentrated at $80^{\circ} \mathrm{C}$.

\section{COLLECTION OF ALBINO RATS}

Twelve adult rats were obtained from the zoology department and was transported to the Biochemistry department both in University of Nigeria, Nsukka.

\section{SAMPLE PREPARATION}

\section{ANIMAL TREATMENT}

The animals were acclimatizes for one week, weighed and placed in four groups (A-D) of three animals each. They were allowed free access to water and food throughout the periodic of experiment. The extract amount of drugs administered to each animal was calculated based on body weight.

\section{ANIMAL GROUPS AND TREATMENT}

Animals were placed in four groups (A - D) and daily doses of Gambia Albidium Bark extract in solution were administered to them

Group I: Hepatotoxicity $\left(\mathrm{CCl}_{4}\right)$ without treatment.

Group II: Hepatotoxicity, No treatment.

Group III: G. Albidium Bark extracts ethylacetate and $\mathrm{CCl}_{4}$.

Group IV: G. Albidium Bark extract in ethanol and $\mathrm{CCl}_{4}$.

\section{REAGENT PREPARATION \\ BUFFERED SUBSTRATE}

Buffered substrate was prepared by mixing $2.66 \mathrm{~g}$ of anhydrous di-sodium hydrogen phosphate, $0.86 \mathrm{~g}$ of benzoic acid and $0.4 \mathrm{~g}$ of starch in $100 \mathrm{mkl}$ of distilled water. 


\section{PHENOL REAGENT}

$5 \mathrm{~g}$ of phenol was weighed and $0.002 \mathrm{~g}$ of $\mathrm{Na}$ Nitropruiside was added and dissolved in distilled water and made up to $100 \mathrm{mls}$ (run 1.5 dilution of stock)

\section{NORMAL SALINE}

Dissolved $9 \mathrm{~g}$ of sodium chloride over night and venous blood sample were collected from the albino rats after decapitation. The blood samples were put into sterile specimen bottles (EDTA bottles) and centrifuged for $10 \mathrm{mins}$ at $3000 \mathrm{~g}$, the serum was separated from plasma and the serum was stored in a refrigerator.

\section{DETERMINATION OF PARAMETERS}

ASPARTATE TRANSAMINASE (AST)

$0.5 \mathrm{ml}$ of buffer substrate solution was added to $0.1 \mathrm{ml}$ of serum.

Mix and incubated at $70^{\circ} \mathrm{C}$ for $60 \mathrm{mins}$.

Add $0.5 \mathrm{ml}$ of chromogen solution and mix thoroughly.

Allow to stand for 20mins at room temperature.

Add $5 \mathrm{ml}$ of $0.4 \mathrm{~N} \mathrm{NaOH}$ and mix for $5 \mathrm{mins}$.

Take absorbance at 540nm. (Reitman and Frankel, 1957)

\section{CHOLESTEROL}

Take $0.1 \mathrm{ml}$ of sample and add $\mathrm{ml}$ of ethanol

Put in EDTA bottles, shake for 2 mins

Centrifuge for $5 \mathrm{mins}$

Take $2 \mathrm{ml}$ of clear supernatant into two tubes

Add $2 \mathrm{ml}$ of cholesterol colour reagent and shake vigorously

Allow to stand for 30mins

Take absorbance at 550nm against reagent blank

(Reagent blank: $2 \mathrm{ml}$ of ethanol and co,our reagent). (Ochei and Kol, 2007)

\section{LIPID PEROXIDATION}

Take $0.1 \mathrm{ml}$ of serum

Add $0.9 \mathrm{ml}$ of $\mathrm{H}_{2} \mathrm{O}$

Add $2 \mathrm{ml}$ of $10 \%$ Tri Chloro Acetic acid (TCA)

Mix and centrifuge for $5 \mathrm{mins}$ at $300 \mathrm{~g}$

Transfer $2 \mathrm{ml}$ of Thio Barbituric Acid (TBA)

Boil for $1 \mathrm{hr}$, allow to cool

Take absorbance at $532 \mathrm{~nm}$ against reagent blank

(Blank: $2 \mathrm{ml}$ of TCA and $2 \mathrm{ml}$ of TBA)

\section{PROTEIN}

Take $0.1 \mathrm{ml}$ of serum

Add $5 \mathrm{ml}$ of incubation mixture, mix

After $10 \mathrm{mins}$, add $0.5 \mathrm{ml}$ of phenol reagent, mix

Take absorbance at $700 \mathrm{mins}$ against reagent blank

(Blank: incubation mixture, $0.1 \mathrm{ml}$ of water and phenol reagent) (Lowry, 1951)

\section{BILIRUBIN}

Take $0.1 \mathrm{ml}$ of the sample Add $0.4 \mathrm{ml}$ of distilled water

Add $0.25 \mathrm{ml}$ of diazo reagent

Add $1 \mathrm{ml}$ of caphane reagent, mix

Allow to stand for $15 \mathrm{mins}$

Add $0.05 \mathrm{ml}$ of ascorbic acid

Add $0.75 \mathrm{ml}$ of alkaline tatirate

Take absorbance at 608nm within 30mins. (Every and Molly, 1996) 


\section{Results}

1 TABLE 1: Average weight of rats (per kg body weight)

\begin{tabular}{ll}
\hline GROUPS & WEIGHTS $(\mathbf{g})$ \\
\hline A & 69.33 \\
B & 128.33 \\
C & 149.50 \\
D & 75.00 \\
\hline
\end{tabular}

The table above shows the average weight of rats in the test groups.

CHOLESTEROL DETERMINATION IN THE BODY

Table 2: Average Cholesterol Concentration

\begin{tabular}{ll}
\hline GROUPS & CONCENTRATION $(\mathbf{m g} / \mathbf{1 0 0 m l})$ \\
\hline A & $3.91 \pm 0.602$ \\
B & $5.12 \pm 0.495$ \\
C & $4.15 \pm 0.105$ \\
D & $3.790 \pm 0.235$ \\
\hline
\end{tabular}

All values are in mean \pm standard deviation

The table above shows the mean concentration of cholesterol level in the blood of the albino rats treated with Gambia albidum bark extract.

LIPID PEROXIDATION DETERMINATION IN THE BLOOD

Table 3: Average lipid peroxidation concentration

\begin{tabular}{ll}
\hline GROUPS & CONCENTRATION $(\mathbf{m g} / \mathbf{1 0 0 m l})$ \\
\hline A & $0.026 \pm 0.0027$ \\
B & $0.031 \pm 0.040$ \\
C & $0.029 \pm 0.005$ \\
D & $0.032 \pm 0.002$ \\
\hline
\end{tabular}

All values are in mean \pm standard deviation.

The table above shows the mean concentration of lipid peroxidation products in the blood of the albino rats treated with Gambia albidum bark extract.

\section{PROTEIN DETERMINATION IN THE BLOOD}

Table 4: Average protein concentration

\begin{tabular}{ll}
\hline GROUPS & CONCENTRATION $(\mathbf{m g} / \mathbf{1 0 0 m l})$ \\
\hline A & $0.36 \pm 0.050$ \\
B & $0.42 \pm 0.006$ \\
C & $0.39 \pm 0.009$ \\
D & $0.407 \pm 0.015$ \\
\hline
\end{tabular}

All values are in mean \pm standard deviation.

The table above shows the mean concentration of protein level in the blood of the albino rats treated with Gambia albidum bark extract.

ASPARTATE TRANSAMINASE DETERMINATION IN THE BLOOD

Table 5: Average AST concentration.

\begin{tabular}{ll}
\hline GROUPS & CONCENTRATION $(\mathbf{m g} / \mathbf{1 0 0 m l})$ \\
\hline $\mathrm{A}$ & $145.89 \pm 1.071$ \\
$\mathrm{~B}$ & $135.89 \pm 1.614$ \\
$\mathrm{C}$ & $142.89 \pm 11.042$ \\
$\mathrm{D}$ & $119.33 \pm 2.728$ \\
\hline
\end{tabular}

All values are in mean \pm standard deviation.

The table above shows the mean concentration of aspartate transaminase level in the blood of the albino rats treated with Gambia albidum bark extract.

\section{BILIRUBIN DETERMINATION IN THE BLOOD}

Table 6: Average bilirubin concentration.

\begin{tabular}{ll}
\hline GROUPS & CONCENTRATION $(\mathbf{m g} / \mathbf{1 0 0 m l})$ \\
\hline A & $23.58 \pm 0.764$ \\
B & $16.50 \pm 2.046$ \\
C & $21.92 \pm 3.753$ \\
D & $13.00 \pm 0.750$ \\
\hline
\end{tabular}


All values are in mean \pm standard deviation.

The table above shows the mean concentration of bilirubin level in the blood of the albino rats treated with Gambia albidum bark extract.

\section{Discussion}

The hepatoprotective effect of Gambia albidum bark extract was carried out on albino rats after induction of hepatotoxicity woth carbon tetrachloride $\left(\mathrm{CCl}_{4}\right)$. Ethanol and ethyl acetate extract of Gambia albidum were administratered to the rats for its hepatoprotective effects. The first group of rats (group A) was given only $\mathrm{CCl}_{4}$ while the second group (group B) was not given anything, the third group (group C) was treated with ethanol extract while the fourth group (group D) was treated with ethyl acetrate extract.

In the course of administration of Gambia albidum bark extracts, the treated animals showed a decrease in physical activity i.e. decreases movement and alertness compared to the control group which was physically normal. The biochemical reason for this observation could be as a result of the metabolic response of the animals (i.e., activation) to the constituents of the Gambia albidum bark extract. (Lopez, 1999).

There was a decrease in food and water intake observed in treated animals with the Gambia albidum bark extract in comparism with the control and this may be linked to loss of appetite (Lopez, 1999). This could explain the decrease in the physical activities of the animals.

There was a marked increase in AST activities. This may be due to hepatobilitiary injury causing the enzyme to leak from the liver into the blood stream, thereby increasing their serum levels (Kelly, 2000).

The exposure of the test animals ethyl acetate extract brought about a slight increase in lipid peroxidation level $(\mathrm{mg} / 100 \mathrm{ml}$ ) from $0.026 \pm 0.00027$ (negative control A) to $0.031 \pm 0.040$ (positive control B) to $0.32 \pm 0.0027$ (group D). This was suggestive of a moderate protective effect of ethyl acetate extract in the rats. There was decrease in cholesterol level $(\mathrm{mg} / 100 \mathrm{ml}$ ) from $5.12 \pm 00.495$ (positive control B) to $3.91 \pm 0.602$ (negative control A) to $3.790 \pm 0.235$ (group D). There was a decrease in protein level $(\mathrm{mg} / 100 \mathrm{ml}$ ) from $0.42 \pm$ 0.006 (positive control B) to $0.0407 \pm 0.015$ (group D) and an increase in protein level from $0.36 \pm 0.050$ (negative control A) to 0.015 (group D). There was a decrease in bilirubin level (mg/100ml) from $23.58 \pm 0.764$ (negative control B) to $16.50 \pm 2.064$ (positive control A) to $13.00 \pm 0.750$ (group D). There was a decrease in AST level (mg/100ml) from $145.89 \pm 0.71$ (negative control A) to $135.89 \pm 1.614$ (positive control B) to 119.33 \pm 2.728 (group D). This suggests that there was a moderate protective effect of ethyl acetate extract in the rats.

The exposure of the text animals to ethanol extract brought about decrease in lipid peroxidation level $(\mathrm{mg} / 100 \mathrm{ml}$ ) from $0.031 \pm 0.014$ (positive control B) to $0.029 \pm 0.005$ (group C), there was an increase in lipid peroxidation level from $0.26 \pm 0.0027$ (negative control B) to $0.029 \pm 0.0 .005$ (group C). This suggests a moderate effect of ethanol extract in the rats. There was a decrease in cholesterol level $(\mathrm{mg} / 100 \mathrm{ml})$ from $5.12 \pm$ 0.495 (positive control B) to $4.15 \pm 0.105$ (group C), there was an increase in cholesterol level from $3.91 \pm$ 0.602 (negative control A) to $4.15 \pm 0.105$ (group C). There was a decrease in protein level $(\mathrm{mg} / 100 \mathrm{ml}$ ) from $0.42 \pm 0.006$ (positive control B) to $0.39 \pm 0.009$ (group C), there was an increase in protein level from $0.36 \pm$ 0.050 (negative control B) to $0.39 \pm 0.009$ (group C). There was a decrease in bilirubin level (mg/100ml) from $23.58 \pm 0.764$ (negative control A) to $21.92 \pm 3.753$ (group C) and there was an increase in bilirubin level from $16.50 \pm 2.046$ (positive control B) to $21.92 \pm 3.753$ (group C). There was an increase in AST level (mg/100ml) from $145.89 \pm 1.071$ (negative group A) to $142.89 \pm 11.042$ (group C), there was a decrease in AST level from $135.89 \pm 1.614$ (positive control B) to $142.89 \pm 11.042$ (group C). this suggests that there was a moderate effect of ethanol extract in the rats.

\section{Conclusion}

In conclusion, all the extract of Gambia albidum (ethanol and ethyl acetate) was moderately effective in providing hepatoprotective effects on the albino rats studied.

\section{References}

[1]. Kelly, G.S., (2000). Insulin Resistance. Life Style and Nutritional Intervention.Alternative Medical Review, 5(2): 109-132.

[2]. Lopez, A.M. (1999). Plants Extracts with Cytostatic Properties. Cubana Med. Trop 31(2): 97-99.

[3]. Ochei, J and Kol, K. (2007). A medical Laboratory Science, Theory and Practice. Sixth edition. Tata McGraw-Hill Publishing Company, New Delhi.

[4]. Reitman, S.N. and Frankel, S.A. (1957). A Colorimetric Method for the Determination of Glutamic Pyrivic Transaminase and Glutamic Oxaloacetate Transaminase. American Journal of Clinical Pathology. Vol. 28:56-63,

[5]. World Health Organization (1978). The Promotion Development of Traditional Medicine, Report of WHO meeting, WHO Technical Report series. 22:23-47. 